\title{
Synthesis, Biological Evaluation and Docking Studies of Some Novel (E)-(4-(2-(benzo[d]thiazol-2-yl)hydrazono)methyl-2,6-diphenylpiperidin-1- yl)(phenyl)methanone Derivatives
}

\author{
D. Rajaraman, G. Sundararajan and K. Krishnasamy ${ }^{*}$ \\ Department of Chemistry, Annamalai University, Annamalainagar-608002, Tamilnadu, India. \\ "Corresponding Author \\ Email: krishnasamybala56@gmail.com \\ Tel.: +919942547856
}

\begin{abstract}
Keywords: Piperidin-4-ones; 2-Hydrazinobenzothiazole; Molecular Docking; Antibacterial activity; Antifungal activity.
\end{abstract}

\begin{abstract}
A series of biologically active some novel (E)-(4-(2-(benzo[d] thiazol-2yl)hydrazono)-3-methyl-2,6-diphenylpiperidin-1-yl)(phenyl)methanone derivatives (14-19) were synthesized and characterized by IR, ${ }^{1} \mathrm{H}$ NMR, ${ }^{13} \mathrm{C}$ NMR and HSQC spectral analysis. Molecular docking studies were also carried out for compounds 14-19 using the crystal structure of Ribonucleotide Reductase to disclose the binding mode and orientation of target molecule into the active site of respective receptors. The synthesized compounds were also screened for their antimicrobial activity against selected panel strains Antimicrobial studies revealed that the synthesized compound $\mathbf{1 4}$ exhibited noticeable activity against B.cerus whereas compounds $\mathbf{1 7}$ and 18 displayed appreciable activity against K.pneumoniae. Bromo substituted phenyl group at C-2 and C-6 of piperidine ring showed excellent antibacterial activity against K.pneumoniae and B.cerus at MIC of $25 \mu \mathrm{g} / \mathrm{ml}$. The antifungal studies revealed that compounds 17, 18 and 19 exposed significant antifungal activity against the pathogenic strains used in this study. In particular compound 19 are showed excellent antifungal activity against C.albicans and A.niger.
\end{abstract}

\section{Introduction}

Nitrogen containing heterocycles always signified a subject of great interest due to their ubiquity in nature and massive presence as part of the skeletal backbone of many therapeutic agents [1]. Piperidin-4-one nucleus are interested to study because of their broad spectrum of biological activities such as antibacterial and antifungal [2-3] local anesthetic [4] antiviral [5] antitumor [6]. The utility of substituent's at second, third and sixth positions, particularly aromatic substituent at second and/or sixth positions with regard to its biological activity have well documented by many workers [7-8]. Hydrazone derivatives have been claimed to exhibit appreciable antimicrobial [9-12] antitubercular [13] anticonvulsant [14] antiviral [15] and anti-inflammatory [16] activities.

Ribonucleotide Reductase (RNR) is a ubiquitous cytosolic enzyme in the cell, responsible for converting ribonucleotides into deoxyribonucleotides, the eventual substrates for DNA polymerase [17-19] and also repairs DNA in all living cells [20]. In mammalian cells, this enzyme contains two dissimilar protein components (R1 and R2) which are encoded by two different genes located on different chromosomes [21]. Protein R1 is a homodimeric structure, with a molecular mass of $168 \mathrm{kDa}$ and has substrate and allosteric effector sites that control enzyme activity and substrate specificity. Protein R2 is a homodimer with a molecular mass of $88 \mathrm{kDa}$ and forms two equivalent dinuclear iron centers that stabilize a tyrosyl free radical, required for the initiation of electron transformation during catalysis. R1 and R2 proteins interact at their C-terminal ends to form an active holoenzyme [19].

On the basis of literature importances, we have the impetus to synthesize a number of hydrazones of the synthetically accessible 2,6-diarylpiperidin-4-one derivatives with a prospect to incorporate diverse bioactive heterocyclic nucleus intact for evaluating their antibacterial and antifungal activity. The docking study was also performed for the crystal structure of human RNR 
with (E)-(4-(2-(benzo[d]thiazol-2-yl)hydrazono)methyl-2,6-diphenylpiperidin-1yl)(phenyl) methanone and the observed results were suitably interpreted.

\section{EXPERIMENTAL SECTION}

\subsection{MATERIALS AND METHODS}

All the reported melting points were taken in open capillaries and are uncorrected. IR spectra were recorded in AVATAR-330 FT-IR spectrophotometer (Thermo Nicolet) and only noteworthy absorption levels (reciprocal centimeters) are listed. ${ }^{1} \mathrm{H}$ NMR spectra were recorded at $400 \mathrm{MHz}$ on Bruker AMX $400 \mathrm{MHz}$ spectrometer using $\mathrm{CDCl}_{3}$ as solvent and TMS as an internal Standard. ${ }^{13} \mathrm{C}$ NMR spectra were recorded at $100 \mathrm{MHz}$ on Bruker AMX $400 \mathrm{MHz}$ spectrometer in $\mathrm{CDCl}_{3}$. The tubes used for recording NMR spectra are of $5 \mathrm{~mm}$ diameter. The reagents and solvents used were of high grade and purchased from Himedia and Merck and the solvents were distilled prior to use.

\subsection{Molecular docking}

\subsubsection{Target protein structure preparation}

The three dimensional structure of target protein was obtained from protein data bank (http// www.rcsb.org/pdb). During the docking process, water molecules of crystallization were removed from the complex and hydrogen atoms were added to the structure. The protein was optimized. Partial atomic charges were also assigned according to the force field. Minimizations were performed until the average root mean square deviation of the non-hydrogen atoms reached $5 \AA$ using OPLS-2005 force field to remove the steric hindrance using the protein preparation wizard of Schrödinger (Maestro 9.3.5 version).

\subsubsection{Ligand structure preparation}

The structure is imported in to the software's workspace and energy minimized using two algorithms: steepest descent and conjugate gradient of the impact module having default force field. Receptor Grid Generation program was used to prepare 4BMO Grid and all ligands were optimized by LigPrep program by using OPLS-2005 force field to generate lowest energy state of ligands.

\subsection{Synthesis}

2.3.1. General procedure for synthesis of N-benzoyl-2, 6-diarylpiperidin-4-one (7-12)

Piperdin-4-one $(0.01 \mathrm{~mol})$ and triethylamine $(0.01 \mathrm{~mol})$ in $30 \mathrm{~mL}$ of dry benzene, benzoylchloride $(0.01 \mathrm{~mol})$ in $20 \mathrm{~mL}$ of benzene was added dropwise through the separating funnel for about half an hour. Stirring was continued with $\left(0^{\circ} \mathrm{C}\right)$ a magnetic stirrer. After the completion of the reaction, it was poured into water and extracted with ether in three $50 \mathrm{~mL}$ portion. The combined ether extract was then washed well with 3\% sodium bicarbonate solution and dried over anhydrous sodium sulphate. This upon evaporation and subsequent recrystallization in distilled ethanol furnished the compound (7) in pure form with good yield. The compounds (8-12) were also synthesized adopting the similar procedure.

\subsubsection{Synthesis of 2-hydrazinobenzothiazole (13)}

Equimolar solution of 2-mercaptobenzothiazole $(0.01 \mathrm{~mol})$ and hydrazine hydrate $(0.01 \mathrm{~mol})$ in methanol $(20 \mathrm{~mL})$ was refluxed on a steam bath for about $10 \mathrm{hrs}$. The obtained filtrate was washed with ice water. The product was dried and recrystallized from ethanol to yield the pure compound, yield $60 \%$, m.p. $201-205^{\circ} \mathrm{C}$.

2.3.3. General procedure for the synthesis of (Z)-(4-(2-(benzo[d] thiazol-2-yl)hydrazono)-3-methyl2,6-diphenylpiperidin-1-yl)(phenyl)methanone (14-19)

A mixture of N-benzoyl-2,6-diarylpiperidine-4-one $(0.01 \mathrm{~mol})$ in methanol and 2-hydrazinobenzothizole (HBT) $(0.01 \mathrm{~mol})$ was added with constant stirring and the reaction mixture was refluxed on a water bath. The completion of the reaction was monitored by TLC. The obtained product was filtered and then washed with water. The product was purified by column chromatography (Ethyl acetate \& Hexane 1:4 ratio). All the synthesized compounds were obtained in good yield (Table 1). 
Table 1. Analytical data of 14-19

\begin{tabular}{cccccccc} 
Compounds & $\mathbf{R}$ & $\mathbf{R}_{\mathbf{1}}$ & $\mathbf{R}_{\mathbf{2}}$ & Yield (\%) & $\mathbf{M . F}$ & $\mathbf{M . W}$ & $\left.\mathbf{m . p ~ (}{ }^{\circ} \mathbf{c}\right)$ \\
\hline $1,7,14$ & $\mathrm{H}$ & $\mathrm{H}$ & $\mathrm{CH}_{3}$ & 68 & $\mathrm{C}_{32} \mathrm{H}_{28} \mathrm{~N}_{4} \mathrm{OS}$ & 516.66 & $168-170$ \\
$2,8,15$ & $\mathrm{CH}_{3}$ & $\mathrm{H}$ & $\mathrm{CH}_{3}$ & 64 & $\mathrm{C}_{34} \mathrm{H}_{32} \mathrm{~N}_{4} \mathrm{OS}$ & 544.71 & $169-172$ \\
$3,9,16$ & $\mathrm{OCH}_{3}$ & $\mathrm{H}$ & $\mathrm{CH}_{3}$ & 69 & $\mathrm{C}_{34} \mathrm{H}_{32} \mathrm{~N}_{4} \mathrm{O}_{3} \mathrm{~S}$ & 576.71 & $165-168$ \\
$4,10,17$ & $\mathrm{~F}$ & $\mathrm{H}$ & $\mathrm{CH}_{3}$ & 64 & $\mathrm{C}_{32} \mathrm{H}_{26} \mathrm{~N}_{4} \mathrm{OSF}_{2}$ & 552.64 & $172-175$ \\
$5,11,18$ & $\mathrm{Cl}$ & $\mathrm{H}$ & $\mathrm{CH}_{3}$ & 63 & $\mathrm{C}_{32} \mathrm{H}_{26} \mathrm{~N}_{4} \mathrm{OSCl}_{2}$ & 585.55 & $174-176$ \\
$6,12.19$ & $\mathrm{Br}$ & $\mathrm{H}$ & $\mathrm{CH}_{3}$ & 70 & $\mathrm{C}_{32} \mathrm{H}_{26} \mathrm{~N}_{4} \mathrm{OSBr}_{2}$ & 674.45 & $167-171$
\end{tabular}

2.3.4. (E)-(4-(2-(benzo[d] thiazol-2yl)hydrazono)methyl-2,6-diphenylpiperidin-

$1 y l)($ phenyl)methanone derivatives (14)

White solid: m.p. $168-170^{\circ} \mathrm{C}$ and yield $68 \%$. IR $(\mathrm{KBr})\left(\mathrm{cm}^{-1}\right): 3063,2964,2920$ and 2843

(C-H stretching); and $1632(\mathrm{~N}-\mathrm{C}=\mathrm{O}$ stretching); 1594 (C=N stretching); and 3310 ( $\mathrm{NH}$ stretching).

${ }^{1} \mathrm{H}$ NMR (400 $\left.\mathrm{MH}_{\mathrm{Z}}-\mathrm{CDCl}_{3} \mathrm{ppm}\right): \delta 0.92\left(\mathrm{~d}, 3 \mathrm{H}, \mathrm{CH}_{3}, \mathrm{~J}=4 \mathrm{H}_{\mathrm{Z}}\right), 2.00\left(\mathrm{t}, 1 \mathrm{H}, \mathrm{H}_{5 \mathrm{a}}, \mathrm{J}=1.8 \mathrm{H}_{\mathrm{Z}}\right) ; 2.23(\mathrm{~s}$, $\left.1 \mathrm{H}, \mathrm{H}_{3 \mathrm{a}}\right), 3.52\left(\mathrm{~d}, 2 \mathrm{H}, \mathrm{H}_{2 \mathrm{a}}, \mathrm{H}_{5 \mathrm{e}}, \mathrm{J}=2 \mathrm{H}_{\mathrm{Z}}\right), 3.85\left(\mathrm{~d}, 1 \mathrm{H}, \mathrm{H}_{6 \mathrm{a}}, \mathrm{J}=3.5 \mathrm{H}_{\mathrm{Z}}\right) 6.95(\mathrm{~s}, 1 \mathrm{H}$, hydrazine $\mathrm{NH}), 7.02-$ $7.87\left(\mathrm{~m}, 17 \mathrm{H}\right.$, aromatic protons). ${ }^{13} \mathrm{C} \mathrm{NMR}$ ( $\left.100 \mathrm{MH}_{\mathrm{Z}}-\mathrm{CDCl}_{3} \mathrm{ppm}\right): \delta 170.49(\mathrm{CO}), 165.11(\mathrm{C}=\mathrm{N})$, $157.90(\mathrm{C}-4, \mathrm{C}=\mathrm{N}), 118.06-137.02$ (aromatic and ipso carbon), $77.04(\mathrm{C}-2), 60.07$ (C-6), 37.02 (C3), $29.72(\mathrm{C}-5), 14.22$ (CH3).

2.3.5. (E)-(4-(2-(benzo[d] thiazol-2-yl)hydrazono)-3-methyl-2,6-di-p-tolylpiperidin-1yl)(phenyl)methanone (15)

White solid: m.p. $169-172^{\circ} \mathrm{C}$ and yield $64 \%$. IR (KBr) $\left(\mathrm{cm}^{-1}\right): 2920,2849(\mathrm{C}-\mathrm{H}$ stretching) and $1632\left(\mathrm{~N}-\mathrm{C}=\mathrm{O}\right.$ stretching); $1605\left(\mathrm{C}=\mathrm{N}\right.$ stretching); and $3310\left(\mathrm{NH}\right.$ stretching); ${ }^{1} \mathrm{H}$ NMR (400 $\left.\mathrm{MH}_{\mathrm{Z}}-\mathrm{CDCl}_{3} \mathrm{ppm}\right): \delta 1.05\left(\mathrm{~d}, 1 \mathrm{H}, \mathrm{CH}_{3} \mathrm{~J}=2 \mathrm{H}_{\mathrm{Z}}\right), 1.27\left(\mathrm{~m}, 6 \mathrm{H}, \mathrm{PhCH}_{3}\right), 2.19\left(\mathrm{t}, 1 \mathrm{H}, \mathrm{H}_{5 \mathrm{a}}, \mathrm{J}=2.6 \mathrm{H}_{\mathrm{Z}}\right)$, $2.06\left(\mathrm{~s}, 1 \mathrm{H}, 3_{\mathrm{a}}\right), 3.20\left(\mathrm{~m}, 2 \mathrm{H}, \mathrm{H}_{2 \mathrm{a}}, \mathrm{H}_{5 \mathrm{e}}\right), 4.13\left(\mathrm{q}, 1 \mathrm{H}, \mathrm{H6}_{\mathrm{a}}\right), 6.90(\mathrm{~s}, 1 \mathrm{H}, \mathrm{NH}), 6.92-7.66(\mathrm{~m}, 17 \mathrm{H}$, aromatic proton). ${ }^{13} \mathrm{C} \mathrm{NMR}\left(100 \mathrm{MH}_{\mathrm{Z}}-\mathrm{CDCl}_{3} \mathrm{ppm}\right): \delta 169.08,(\mathrm{CO}), 168.9(\mathrm{C}=\mathrm{N}), 158.5((\mathrm{C}-4$, $\mathrm{C}=\mathrm{N}), 121.35-137.08$ (aromatic and ipso carbon), $77.03(\mathrm{C}-2), 60.42(\mathrm{C}-6), 29.71\left(\mathrm{Ph}-\mathrm{CH}_{3}\right), 21.09$ (C-3), 20.99 (C-5), $14.65\left(\mathrm{CH}_{3}\right)$.

2.3.6. (E)-(4-(2-(benzo[d] thiazol-2-yl)hydrazono)-2,6-bis(4-methoxyphenyl)-3-methylpiperidin-1yl)(phenyl)methanone (16)

White solid: m.p. $165-168^{\circ} \mathrm{C}$ and yield 69\%. IR (KBr) $\left(\mathrm{cm}^{-1}\right): 2964,2920,2849$ and 2832 (C-H stretching) and $1616(\mathrm{~N}-\mathrm{C}=\mathrm{O}$ stretching); $1556(\mathrm{C}=\mathrm{N}$ stretching); and $3420(\mathrm{NH}$ stretching); ${ }^{1} \mathrm{H}$ NMR $\left(400 \mathrm{MH}_{\mathrm{Z}}-\mathrm{CDCl}_{3} \mathrm{ppm}\right): \delta 0.91\left(\mathrm{~d}, 1 \mathrm{H}, \mathrm{CH}_{3} \mathrm{~J}=2.4 \mathrm{H}_{\mathrm{Z}}\right), 2.13\left(\mathrm{t}, 1 \mathrm{H}, \mathrm{H}_{5 \mathrm{a}} \mathrm{J}=24 \mathrm{H}_{\mathrm{Z}}\right), 2.47(\mathrm{~s}$, $\left.1 \mathrm{H}, \mathrm{H}_{3 \mathrm{a}}\right), 2.92\left(\mathrm{~d}, 2 \mathrm{H}, \mathrm{H}_{2 \mathrm{a}}, \mathrm{H}_{5 \mathrm{e}} \mathrm{J}=8 \mathrm{H}_{\mathrm{Z}}\right), 3.73\left(\mathrm{~m}, 6 \mathrm{H}, \mathrm{OCH}_{3}\right), 4.14\left(\mathrm{~d}, 1 \mathrm{H}, \mathrm{H}_{6 \mathrm{a}}, \mathrm{J}=1.8 \mathrm{H}_{\mathrm{Z}}\right), 6.62(\mathrm{~s}, 1 \mathrm{H}$, hydrazine $\mathrm{NH}), 6.75-7.56\left(\mathrm{~m}, 17 \mathrm{H}\right.$, aromatic proton). ${ }^{13} \mathrm{C} \mathrm{NMR}\left(100 \mathrm{MH}_{\mathrm{Z}}-\mathrm{CDCl}_{3} \mathrm{ppm}\right): \delta 171.49$ $(\mathrm{CO}), 168.16(\mathrm{C}=\mathrm{N}), 159.09(\mathrm{C}-4, \mathrm{C}=\mathrm{N}), 113.37$-135.36 (aromatic and ipso carbon), $77.03(\mathrm{C}-2)$, 68.66 (C-6), 36.53 (C-3), $29.72(\mathrm{C}-5), 21.08\left(\mathrm{CH}_{3}\right)$.

2.3.7. (E)-(4-(2-(benzo[d] thiazol-2-yl)hydrazono) -2,6-bis (4-fluorophenyl) -3-methyl piperidin$1 y l)$ (phenyl)methanone (17)

White solid: m.p. $172-175^{\circ} \mathrm{C}$ and yield 64\%. IR (KBr) $\left(\mathrm{cm}^{-1}\right): 3020,2949,2836,2815$ and $2854(\mathrm{C}-\mathrm{H}$ stretching); and $1710 \quad(\mathrm{~N}-\mathrm{C}=\mathrm{O}$ stretching); $1585(\mathrm{C}=$ Nstretching $)$ and $3200(\mathrm{NH}$ stretching); ${ }^{1} \mathrm{H}$ NMR (400 $\left.\mathrm{MH}_{\mathrm{Z}}-\mathrm{CDCl}_{3} \mathrm{ppm}\right): \delta 1.13\left(\mathrm{~d}, 1 \mathrm{H}, \mathrm{CH}_{3} \mathrm{~J}=2 \mathrm{H}_{\mathrm{Z}}\right), 1.90\left(\mathrm{~s}, \mathrm{IH}, \mathrm{H}_{5 \mathrm{a}}\right), 2.89(\mathrm{t}$, $\left.1 \mathrm{H}, \mathrm{H}_{3 \mathrm{a},} \mathrm{J}=1.5 \mathrm{H}_{\mathrm{Z}}\right), 3.23\left(\mathrm{t}, 1 \mathrm{H}, \mathrm{H}_{5 \mathrm{e}}, \mathrm{J}=2 \mathrm{H}_{\mathrm{Z}}\right), 3.71\left(\mathrm{~d}, 1 \mathrm{H} . \mathrm{H}_{2 \mathrm{a}}, \mathrm{J}=1.2 \mathrm{H}_{\mathrm{Z}}\right), 3.8\left(\mathrm{~d}, 1 \mathrm{H}, \mathrm{H} 6 \mathrm{a}, \mathrm{J}=3 \mathrm{H}_{\mathrm{Z}}\right), 6.7$ $(\mathrm{s}, 1 \mathrm{H}$, hydrazine $\mathrm{NH}), 6.79-7.64(\mathrm{~m}, 17 \mathrm{H}$, aromatic protons $) .{ }^{13} \mathrm{C} \mathrm{NMR}\left(100 \mathrm{MH}_{\mathrm{Z}}-\mathrm{CDCl}_{3} \mathrm{ppm}\right): \delta$ 173.49 (ph-CO), $169.11(\mathrm{C}=\mathrm{N}), 162.90(\mathrm{C}-4, \mathrm{C}=\mathrm{N}), 114.79-136.75$ (aromatic and ipso carbon), 77.30 (C-2), 77.05 (C-6), 76.79 (C-3), 53.45 (C-5), $29.88\left(\mathrm{CH}_{3}\right)$. 
2.3.8. (E)-(4-(2-(benzo[d] thiazol-2-yl)hydrazono)-2, 6-bis(4-chlorophenyl)-3-methylpiperidin-1yl)(phenyl)methanone (18)

White solid: m.p. $174-176^{\circ} \mathrm{C}$ and yield63\%. IR (KBr) $\left(\mathrm{cm}^{-1}\right): 3020,2949,2836,2815$ and 2854 (C-H stretching) and $1710(\mathrm{~N}-\mathrm{C}=\mathrm{O}$ stretching); $1585(\mathrm{C}=\mathrm{N}$ stretching); and $3210(\mathrm{NH}$ stretching); ${ }^{1} \mathrm{H}$ NMR (400 $\left.\mathrm{MH}_{\mathrm{Z}}-\mathrm{CDCl}_{3} \mathrm{ppm}\right): \delta 0.84\left(\mathrm{~d}, 1 \mathrm{H}, \mathrm{CH}_{3} \mathrm{~J}=0.8 \mathrm{H}_{\mathrm{Z}}\right), 2.06(\mathrm{t}, 1 \mathrm{H}$, $\left.{ }_{\mathrm{H} 5 \mathrm{a}} \mathrm{J}=0.4 \mathrm{H}_{\mathrm{Z}}\right), 2.61\left(\mathrm{~m}, 1 \mathrm{H}, \mathrm{H}_{3 \mathrm{a}}\right), 3.52\left(\mathrm{~d}, 2 \mathrm{H}, \mathrm{H}_{2 \mathrm{a}}, \mathrm{H}_{5 \mathrm{e}}, \mathrm{J}=1.2 \mathrm{H}_{\mathrm{z}}\right), 3.77\left(\mathrm{~d}, 1 \mathrm{H}, \mathrm{H}_{6 \mathrm{a}} \mathrm{J}=1.6 \mathrm{H}_{\mathrm{Z}}\right), 6.85(\mathrm{~s}$, $1 \mathrm{H}$, hydrazine $\mathrm{NH}), 7.12-7.62\left(\mathrm{~m}, 17 \mathrm{H}\right.$, aromatic proton). ${ }^{13} \mathrm{C} \mathrm{NMR}\left(100 \mathrm{MH}_{\mathrm{Z}}-\mathrm{CDCl}_{3} \mathrm{ppm}\right): \delta$ $170.28(\mathrm{CO}), 155.10(\mathrm{C}=\mathrm{N}), 149.62(\mathrm{C}-4, \mathrm{C}=\mathrm{N}), 118.00-141.33$ (aromatic and ipso carbon), 68.34 (C-2) 59.83 (C-6), 45.01 (C-3), 36.73 (C-5), $\left.12.07 \mathrm{CH}_{3}\right)$.

2.3.9. (E)-(4-(2-(benzo[d] thiazol-2-yl)hydrazono)-2,6-bis(4-brmophenyl)-3-methylpiperidin-1yl)(phenyl)methanone (19)

White solid: m.p. $167-171^{\circ} \mathrm{C}$ and yield 70\%. IR (KBr) $\left(\mathrm{cm}^{-1}\right): 3052$ 2969, 2936, 2915 and $2854(\mathrm{C}-\mathrm{H}$ stretching) and $1720(\mathrm{~N}-\mathrm{C}=\mathrm{O}$ stretching $) ; 1605(\mathrm{C}=\mathrm{Nstretching})$ and $3200(\mathrm{NH}$ stretching); ${ }^{1} \mathrm{H} \mathrm{NMR}\left(400 \mathrm{MH}_{\mathrm{Z}}-\mathrm{CDCl}_{3} \mathrm{ppm}\right): \delta 0.83\left(\mathrm{~d}, 1 \mathrm{H}, \mathrm{CH}_{3}, \mathrm{~J}=1.4 \mathrm{H}_{\mathrm{Z}}\right), 1.30\left(\mathrm{t}, 1 \mathrm{H}, \mathrm{H}_{5 \mathrm{a}}, \mathrm{J}=2 \mathrm{H}_{\mathrm{Z}}\right)$, $2.61\left(\mathrm{~m}, 1 \mathrm{H}, \mathrm{H}_{3 \mathrm{a}}\right), 3.59\left(\mathrm{~d}, 2 \mathrm{H}, \mathrm{H}_{2 \mathrm{a}}, \mathrm{H}_{5 \mathrm{e}} \mathrm{J}=2 \mathrm{H}_{\mathrm{Z}}\right), 4.04\left(\left(\mathrm{~d}, 1 \mathrm{H}, \mathrm{H}_{6 \mathrm{a}} \mathrm{J}=4 \mathrm{H}_{\mathrm{Z}}\right), 6.85(\mathrm{~s}, 1 \mathrm{H}\right.$, hydrazine $\mathrm{NH}), 7.26-8.12$ (m, 17H, aromatic proton). ${ }^{13} \mathrm{C} \mathrm{NMR}\left(100 \mathrm{MH}_{\mathrm{Z}}-\mathrm{CDCl}_{3} \mathrm{ppm}\right): \quad \delta{ }^{13} \mathrm{C} \mathrm{NMR}(100$ $\left.\mathrm{MH}_{\mathrm{Z}}-\mathrm{CDCl}_{3} \mathrm{ppm}\right): \delta 172.00(\mathrm{CO}), 169.80(\mathrm{C}=\mathrm{N}), 158.5(\mathrm{C}-4, \mathrm{C}=\mathrm{N}), 113.00-150.51$ (aromatic and ipso carbon), 61.50 (C-2) 58.3(C-6), 45.01 (C-3), $37.20(\mathrm{C}-5) 12.09\left(\mathrm{CH}_{3}\right)$.

\subsection{Biological Screening}

\subsubsection{Microbiology}

All the bacterial strains namely Klebsiella pneumonia, Bacillus cerus, Salmonella typhi, Escherichia coli, Vibriae cholera and fungal strains namely Candida albicans, Aspergillus niger, Aspergillus flavus, Fusarium oxysporum and Cryptococcus neoformans were obtained from the Department of Microbiology, Annamalai University, Annamalainagar, Tamilnadu, India.

\subsubsection{In Vitro Antibacterial and Antifungal Activity}

The in vitro activities of compounds (14-19) were tested in Sabourauds dextrose broth (SDB) (Himedia, Mumbai) for fungi and nutrient broth (NB) (Himedia, Mumbai) for bacteria by the disc diffusion method. MIC values were determined by twofold serial dilution method (Dhar et al., 1968). The test compounds were dissolved in dimethylsulfoxide (DMSO) to obtain $1 \mathrm{mg} \mathrm{ml}^{-1}$ solution. Seeded broth (broth containing microbial spores) was prepared in nutrient broth from $24 \mathrm{~h}-$ old bacterial cultures on nutrient agar (Himedia, Mumbai) at $37 \pm 1^{\circ} \mathrm{C}$, while fungal spores from 24 $\mathrm{h}$ to 7 days old Sabouraud's agar slant cultures were suspended in SDB. The petriplates are incubated in BOD incubator (Sigma Instruments, Chennai, India) at $37^{\circ} \mathrm{C}$ for bacteria and $28^{\circ} \mathrm{C}$ for fungi. The zone of inhibition is recorded by visual observation after $24 \mathrm{hrs}$ of inhibition for bacteria and after $72-96 \mathrm{hrs}$ of inhibition for fungi. Moreover, the zone of inhibition is measured by excluding the diameter of the paper disc. Streptomycin was used as standard for bacteria and Amphotericin B as standard for fungi under analogous conditions. 


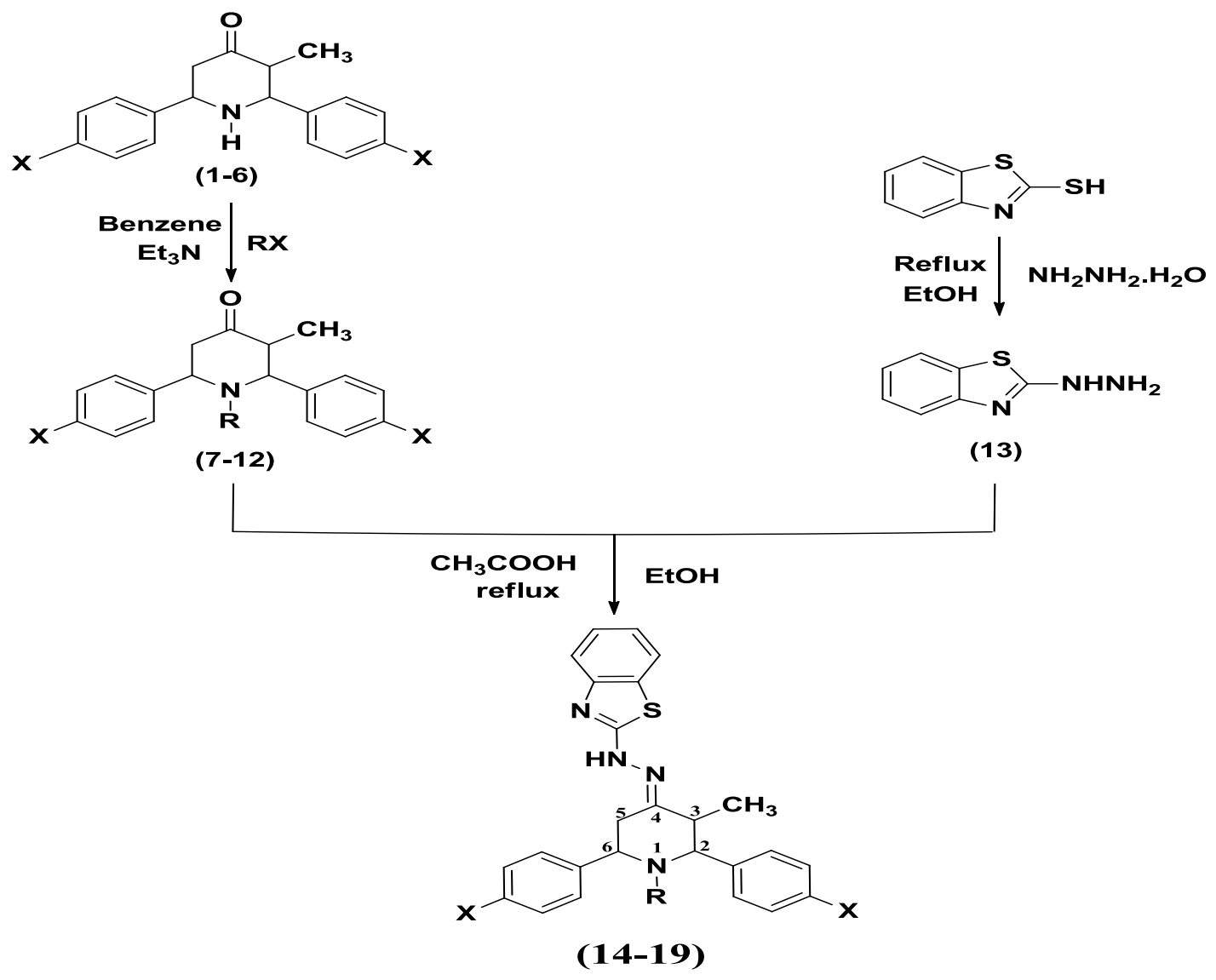

Scheme 1

\section{RESULTS AND DISCUSSION}

\subsection{Analytical Results}

Schematic representation of the synthesized compounds 14-19 depicted in scheme 1 . In this series, the structural interpretation of the representative compound $\mathbf{1 6}$ was discussed as follows. In FT-IR spectrum of compound 16, the disappearance of NH stretching frequency around $3300 \mathrm{~cm}^{-1}$ confirms the complete conversion of $\mathrm{NH}$ into N-benzoylpiperidone and also the $\mathrm{N}-\mathrm{CO}$ bond will have partial double bond character. Hence, two rotamers are possible. However, in no case separate NMR signals corresponding to the two rotamers were seen. Obviously, the rotation about the N-CO bond seems to be fast on NMR time scale. The disappearance of $\mathrm{C}=\mathrm{O}$ stretching frequency around $1710 \mathrm{~cm}^{-1}$ and the presence of $\mathrm{C}=\mathrm{N}$ stretching frequency confirm the formation of hydrazone derivatives (14-19). The weak band appeared at $3420 \mathrm{~cm}^{-1}$ corresponds to the $-\mathrm{NH}$ stretching mode of the thiazole moiety. The aromatic and aliphatic $\mathrm{C}-\mathrm{H}$ stretching vibrations are observed in the range of 2854-3052 $\mathrm{cm}^{-1}$. In ${ }^{1} \mathrm{H}$ NMR spectrum of compound 16, there was a multiplet in the region of 6.85-7.56 ppm corresponding to 17 protons and it is due to the aromatic protons. The $\mathrm{NH}$ proton was assigned as singlet at $6.80 \mathrm{ppm}$ and the methoxy protons were appeared at $3.73 \mathrm{ppm}$ as a doublet and the broadening of benzylic C-6 proton was appeared as doublet in the region of 3.43 ppm. The $\mathrm{H}-2 \mathrm{a}$ proton coupled with $\mathrm{H}-5 \mathrm{e}$ proton and their signal was appeared as doublet in the region of $2.92 \mathrm{ppm}$. The signals appeared at $2.47 \mathrm{ppm}$ and $2.13 \mathrm{ppm}$ was assigned to $\mathrm{H}-3 \mathrm{a}$ and $\mathrm{H}-5 \mathrm{a}$ protons. In ${ }^{13} \mathrm{C}$ NMR spectrum of compound 16, the signals at 77.03, 68.66, 36.53 and $29.72 \mathrm{ppm}$ in the aliphatic region are assigned to C-2, C-6, C-3 and C-5 carbons of the piperidone ring, respectively. The hydrazone carbon (C-4) signal appeared at $159.09 \mathrm{ppm}$ and amide carbonyl carbon signal appeared at $171.49 \mathrm{ppm}$. The aromatic and ipso carbon signals appeared in the region of 113.37-135.36 ppm. From the HSQC spectrum of compound 16, it is evident that benzylic proton at C-6 has cross peak with low intensity signal at $64.50 \mathrm{ppm}$. Thus, it is due to C-6 benzylic carbon. Similarly, the signal at 45.05 ppm shows cross peak with C-2 and C-5 protons confirmed the C-2 
and C-5 protons. The signal at 46.00 ppm shows cross peak with methelinic proton at C-3, it is due to the benzylic carbon at C-3. Further the methoxy protons signal appeared at $3.73 \mathrm{ppm}$ shows cross peaks with corresponding ipso carbon. ${ }^{1} \mathrm{H}$ and ${ }^{13} \mathrm{C}$ NMR signal and it's splitting patterns of compound 14-19 are observed as almost same as of compound $\mathbf{1 4}$.

\subsection{Molecular Docking protocol}

The entire docking calculations were performed using the induced fit docking module of the schrodinger. It performs flexible protein-ligand docking and searches for favorable interactions between one typically small ligand molecule and a typically larger protein molecule. Docking process is divided into three steps. Primary glide docking, wherein protein preparation inhibited refinement is carried out with a maximum of 20 poses. Prime induced fit, wherein the side chains are optimized and refinement of residues takes place, if the ligand poses are within 5.0A. Step 3 consists of the glide redocking step by means of standard precision mode. The best docked structure was chosen by three criterias: glide score function, glide energy and the number of amino acids matches (hydrogen bonds) with original drug complex. Binding interaction of compound with active site residues of RNR is shown in Fig. 1. Molecular analysis of compound $\mathbf{1 9}$ indicated that hydrogen bond, hydrophobic and mild polar interactions are three major interactions incorporating the attachment of this ligand to Ribonucleotide Reductase acceptor. Hydrophilic and hydrophobic interactions are shown in Fig. 2. The two-dimensional interaction diagram of docked compound 19 (Fig.2) revealed that the ligand is surrounded by hydrophobic residues such as TRP74, TYR41, LEU99, PHE45, PHE78, MET77, ALA80 and MET8. This observation concluded that hydrophobic interactions and desolvation effects involved in the binding process. Further the hydrophilic residues like THR42, THR43, ASN71, ASN73, ASN11 and SER69 are situated around the surface of the target ligand 19. Hence binding affinities also enhanced by these hydrophilic residues. In compound 19, the binding interactions are further surprisingly enhanced by $\pi-\pi$ stacking interactions between benzoyl and benzothiazole moieties with TRY74 binding site residue. Among the synthesized compounds 14-19, the para-bromo substituted compound 19 showed moderate G score -4.95 and glide energy $-41.95 \mathrm{kcal} / \mathrm{mol}$. It is indicated that compound 19 has better ligandprotein interactions and reflected that compound 19 will have better antimicrobial character. 
Table 2. G core, glide energy, hydrophilic and hydrophobic interaction of 14-19

\begin{tabular}{|c|c|c|c|c|}
\hline Compounds & G score & $\begin{array}{l}\text { Glide energy } \\
\text { (kcal/mol) }\end{array}$ & $\begin{array}{c}\text { Hydrophobic } \\
\text { interaction residues }\end{array}$ & $\begin{array}{l}\text { Hydrophilic interaction } \\
\text { residues }\end{array}$ \\
\hline 14 & -3.82 & -28.4 & $\begin{array}{l}\text { TRP74, PHE45, ALA80, } \\
\text { MET77, PHE78. }\end{array}$ & $\begin{array}{c}\text { THR43, ASN47, ASN71, } \\
\text { THR42. }\end{array}$ \\
\hline 15 & -3.66 & -37.2 & $\begin{array}{l}\text { TRP74, PHE78, MET77, } \\
\text { PHE45, MET } 8 .\end{array}$ & $\begin{array}{c}\text { THR45, ASN71, THR42, } \\
\text { ASN73, THR9. }\end{array}$ \\
\hline 16 & -3.48 & -25.9 & $\begin{array}{l}\text { TRP74, MET77, MET8, } \\
\text { PHE45. }\end{array}$ & $\begin{array}{c}\text { ASN71, THR42, ASN47, } \\
\text { THR43, THR9. }\end{array}$ \\
\hline 17 & -3.76 & -35.7 & $\begin{array}{l}\text { PHE45, TRP74, MET77, } \\
\text { TYR41, MET8, LEU99. }\end{array}$ & $\begin{array}{l}\text { THR43, THR42, SER69, } \\
\text { ASN71, ASN73. }\end{array}$ \\
\hline 18 & -4.31 & -28.1 & $\begin{array}{l}\text { TRP74, PHE78, MET77, } \\
\text { LEU99, MET8, PHE45. }\end{array}$ & $\begin{array}{c}\text { ASN71, ASN73, THR42, } \\
\text { THR43, THR9. }\end{array}$ \\
\hline 19 & -4.95 & -41.9 & $\begin{array}{l}\text { TRP74, TYR41, LEU99, } \\
\text { PHE45, PHE78, MET77, } \\
\text { ALA80, MET8. }\end{array}$ & $\begin{array}{l}\text { THR42, THR43, ASN71, } \\
\text { ASN73 ASN11, SER69, }\end{array}$ \\
\hline
\end{tabular}

The root-mean-square deviation (RMSD) is the measure of the average distance between the atoms (usually the backbone atoms) of superimposed proteins. Rmsd data calculated for structure pairs of different sizes cannot be compared, because the rmsd value obviously depends on the number atoms included in the structural alignment. The rmsd value of the native ligand is $0.02 \AA$ and the rmsd value of synthesized compound (19) is $0.023 \AA$ from this evident the compound 19 is approximately same size compared to reference ligand. To conclude this observation, the synthesized compounds subjected for antimicrobial studies and the results are interpreted. The experimentally observed microbial results indicated that the compound 19 exhibited excellent antibacterial and antifungal activities. The docking score, glide energy, hydrophilic and hydrophobic interactions of amino acids of compounds 14-19 are given in Table 2 . 

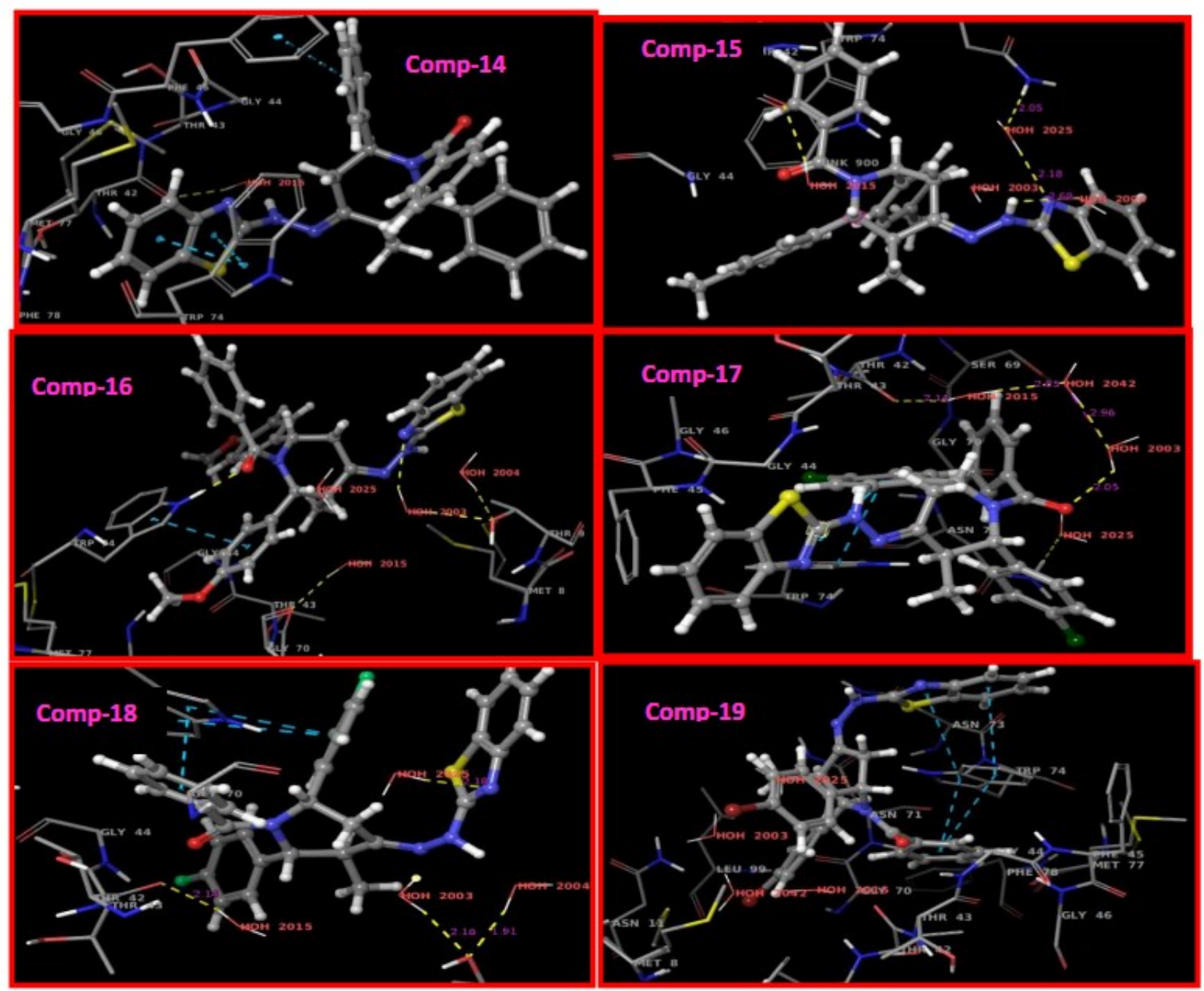

Fig. 1 Binding interaction of 14-19 with active site residues of $4 \mathrm{bmo}$ receptor 

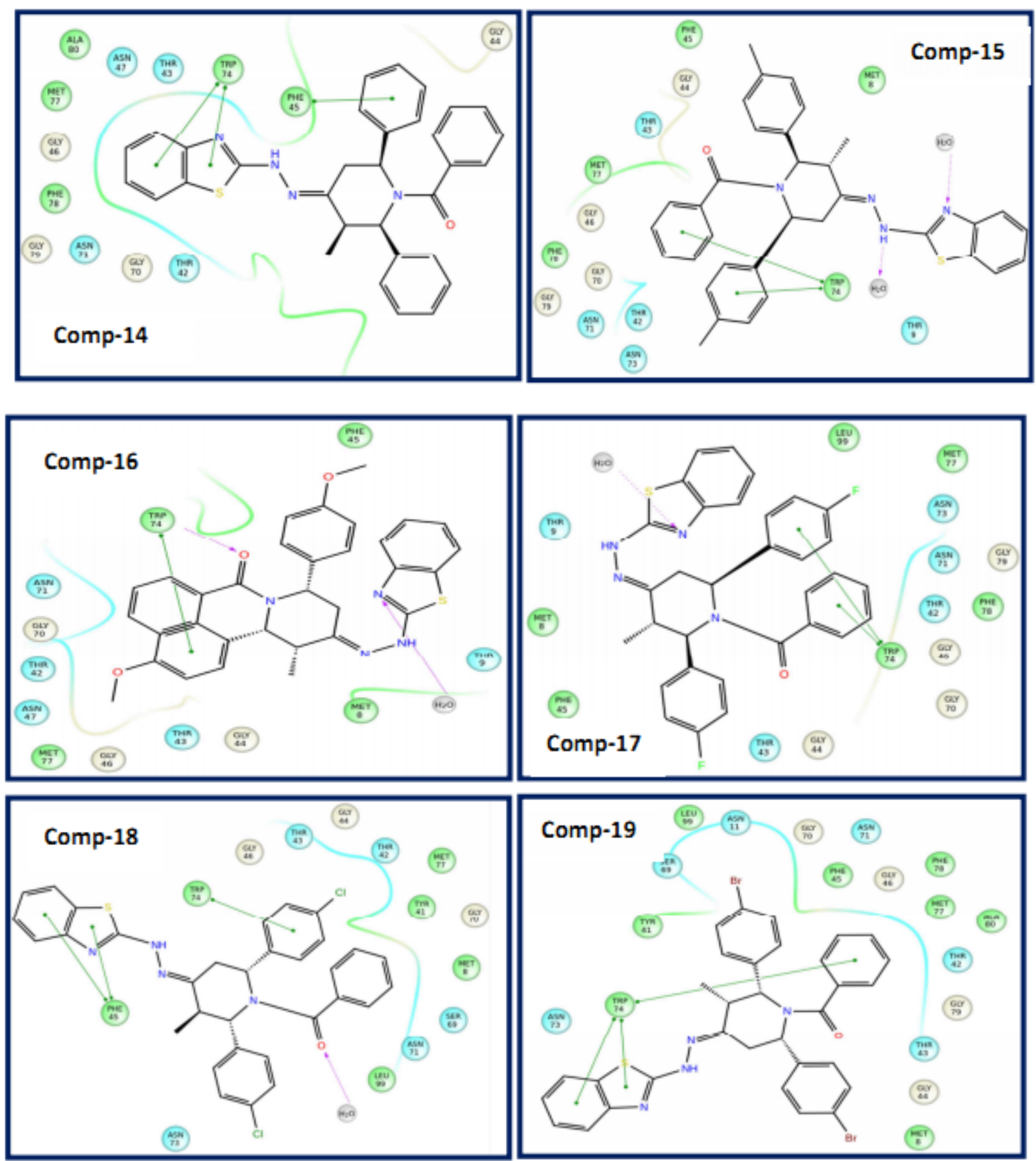

Fig. 2 Hydrophilic and hydrophobic interaction of 14-19

\subsection{Antibacterial Activity}

The synthesized compounds (14-19) were tested for their in vitro antibacterial activity against selected Gram positive and Gram negative pathogens. (E)-(4-(2-(benzo[d]thiazol-2yl)hydrazono)-3-methyl-2,6-diphenylpiperidin-1-yl)(phenyl)methanone (14-19) derivatives exhibited a wide spectrum of antibacterial profile in In vitro against all the tested organisms as shown in Table 3. 
Table 3. Antibacterial activity of $14-19$

\begin{tabular}{cccccc}
\hline Compound & \multicolumn{5}{c}{ Minimum inhibitory concentrations. $\left(\boldsymbol{\mu g} \mathbf{~ m l}^{-1}\right)$} \\
& K.pneumonia & B.cerus & S.typhi & E.coli & V.cholerae \\
\hline $\mathbf{1 4}$ & 200 & 50 & 200 & 150 & 100 \\
$\mathbf{1 5}$ & 100 & - & 200 & 100 & 150 \\
$\mathbf{1 6}$ & 100 & 100 & 200 & 150 & 150 \\
$\mathbf{1 7}$ & 75 & 100 & 150 & - & 100 \\
$\mathbf{1 8}$ & 75 & 100 & 100 & - & 150 \\
$\mathbf{1 9}$ & 25 & 25 & - & 50 & - \\
Streptomycin & 25 & 25 & 25 & 50 & 25 \\
\hline
\end{tabular}

The substitution of methyl group at C-3 position of the six-membered hetrocyclic ring generally increased their antibacterial activity. Compound $\mathbf{1 4}$ without any substituent at para position of aryl groups present at C-2 and C- 6 of piperidone ring exerted moderate antibacterial activity at 50-200 $\mu \mathrm{g} \mathrm{ml}^{-1}$ against the bacterial strains. The methyl substituent on $\mathbf{1 4}$ expressed an appreciable activity against $K$. pnemoniae. The replacement of methyl group at the para position of the aryl group through methoxy functionalities in compound 16, did not show any appreciable antibacterial activity. The fluro substituted compound $\mathbf{1 7}$ exhibited moderate antibacterial activities against B.cerus and V.cholerae. The chloro substituted compound $\mathbf{1 8}$ showed strong bacterial activities against C. K.pneumoniae. The substitution of bromo atom has excellent activity against $K$. pneumonia and and K.pneumoniae B.cerus and E.coli.

\subsection{Antifungal Activity}

The in vitro antifungal activity of compounds (14-19) were examined against the fungal strains viz., Candida albicans, Aspergillus niger, Aspergillus flavus, Cryptococus neoformans and Fusarium oxysporum. Amphotericin B was used as standard drug whose minimum inhibitory concentration values are reproduced in Table 4.

Table 4. Antifungal activity of 14-19

\begin{tabular}{cccccc}
\hline Compound & \multicolumn{5}{c}{ Minimum inhibitory concentrations. $\left(\boldsymbol{\mu g} \mathbf{~ m} \boldsymbol{I}^{-1}\right)$} \\
& C.albicans & A.niger & A.flavus & C.neoformans & F.oxysporum \\
\hline $\mathbf{1 4}$ & 150 & 250 & - & 50 & 250 \\
$\mathbf{1 5}$ & 100 & 50 & 100 & 250 & 200 \\
$\mathbf{1 6}$ & 150 & 50 & 150 & 250 & - \\
$\mathbf{1 7}$ & - & 100 & 50 & 150 & 150 \\
$\mathbf{1 8}$ & 150 & 100 & 100 & 50 & 100 \\
$\mathbf{1 9}$ & 25 & 25 & 50 & 50 & 50 \\
Amphotericin B & 25 & 50 & 25 & 25 & 50
\end{tabular}

Compound 14, without any substituents at the para position of aryl groups at C-2 and C-6 of the six-membered heterocyclic ring has more antifungal activity against $C$. neoformans compared to other fungal strains. The introduction of methyl group at the para position of aryl group at C-2 and C-6 of piperidone ring (compound 15) was found to be better in enhancing the antifungal activity against A.niger compared to other fungal strains. Further, compound $\mathbf{1 6}$ has decrease in fungal activity against all the fungal strains. The substitution of fluoro atom at the para position of aryl group (compound 17) exerted remarkable activity against A.flavus compared to others bacterial 
strains. The chloro substituted compound $\mathbf{1 8}$ exhibited excellent activities against $C$. neoformans compared to other fungal strains. From Table 4, it is obvious that compounds 17, 18 and 19 were recorded excellent antifungal activity.

\section{CONCLUSION}

All the synthesized compounds of (E)-(4-(2-(benzo[d]thiazol-2-yl)hydrazono)-3-methyl-2,6diphenylpiperidin-1-yl)(phenyl)methanone derivatives (14-19) are characterized by IR and NMR spectral data. The chemical shifts and coupling constant values indicated that all the synthesized hydrazone derivatives adopt the chair conformation in which all the alkyl and aryl substituents in the piperidone occupying equatorial orientations. Molecular docking studies revealed that compound 19 has appreciable binding interaction with the active site of the selected protein 4BMO. Compound 19 oriented in the binding site in such a manner that it favour the possibility of $\pi-\pi$ stacking interaction on benzothiazole and benzoyl ring with TRY74. Existence of hydrophilic, hydropobhic and $\pi-\pi$ stacking interaction on target ligand 19 with selected protein $4 \mathrm{BMO}$ is the reason for obtaining low docking score and glide energy. Antimicrobial studies revealed that compound 19 showed excellent antibacterial and antifungal activities as per the results obtained from the docking studies.

\section{Acknowledgements}

The authors K. Krishnasamy and D. Rajaraman thank the university grant commission for the financial support (Major Research Project, F. NO: 42-342/2013) of this research work. The authors extend their thanks to the Department of Microbiology, Annamalai University for the evaluation of antimicrobial studies.

\section{REFERENCES}

[1] R. Jeyaraman, S. Avila, Chemistry of 3- azabicyclo[3.3.1] nonanes. Chem. Rev, 81 (1981) 149.

[2] K. Narayanan, M. Shanmugam, S. Jothivel, S. Kabilan, 1-allyl substituted 2,6diphenylpiperidin-4-ones and derivatives of oximes/ oxime ethers. Bioorg. Med. Chem. Lett. 22 (2012) 6602-6607.

[3] G. Aridoss, S. Balasubramanian, P. Parthiban, S. Kabilan, Synthesis, stereochemistry and antimicrobial evaluation of some N-morpholinoacetyl-2,6-diarylpiperidon-4-ones. European J. Med. Chem. 42 (2007) 851-860.

[4] R. V. Perumal, M. Adiraj, P. Shanmugapandiyan, Synthesis, analgesic and anti- inflammatory evaluation of substituted 4-piperidines. Indian Drugs. 38 (2001) 156-159.

[5] H. I. El-Subbagh, S. M. Abu-Zaid, M. A. Mahran, F. A. Badria, A. M. Alofaid, Synthesis and biological evaluation of certain $\alpha, \beta$ unsaturated ketones and their corresponding fused pyridines as antiviral and cytotoxic agents. J Med. Chem. 43 (2000) 2915.

[6] A. A. Watson, G. W. J. Fleet, N. Asano, R. J. Molyneux, Polyhydroxylated alkaloids-natural occurance and therapeutic application. Photochemistry. 56 (2001) 265.

[7] N. Rameshkumar, A. Veena, R. Ilavarasan, M. Adiraj, P. Shanmugapandiyan, S. Sridhar, Synthesis of 6-fluoro-1,4-dihydro-4-oxo-quinoline-3-carboxlic acid derivatives as potential antimicrobial agents. European. Med. Chem. 26 (2003) 188.

[8] R. V. Perumal, M. Adiraj, P. Shanmugapandiyan, Synthesis, analgesic and antiinflammatory evaluation of substituted 4-piperidines. Indian Drugs. 38 (2001) 156-159.

[9] H. M. Eisa, A. S. Tantaway, M. M. El-Kerdawy, Synthesis of certain 2-aminoadamantane derivatives as potential antimicrobial agents. Pharmazie Mar, 46 (1991) 182-184. 
[10] A. Gursoy, N. Terzioglu, G. Otuk, synthesis of some new hydrazide-hydrazones. Eur J Med Chem. 32 (1997) 753-757.

[11] S. Rollas, N. N. Gulerman, H. Erdeniz. Synthesis and antimicrobial activity of some new hydrazones of 4-fluorotenzoic acid hydrazide and 3-acetyl-2,5-discubstituted-1,3,4 oxadiazolines. J Farmaco. 57 (2002) 171-174

[12] P. Vicini, F. Zani, P. Cozzini, I. Doytchinova, Hydrazones of 1,2-benzisothiazole hydrazides: synthesis, antimicrobial activity and QSAR investigations. Eur J Med Chem. 37 (2002) 553564.

[13] C. Sankar, K. Pandiyarajan, Synthesis and anti-tuberlar and antimicrobial activities of some $2 r, 4 c$ - diaryl-3-azabicyclo[3.3.1] nonan-9-one $N$-isonicoylhydrazone derivatives. Eur J Med Chem. 45 (2010) 5480-5485.

[14] Neeraj Kumar.; Lalit Singh Chauhan.; Nipun Dashora.; Chandra Shekhar Sharma. Anticonvulant potential of Hydrazone derivatives: A Review. Sch. Acad. J. Pharm, 3 (2014) 366-373.

[15] O. I. El-sabbagh, H. M. Rady, Synthesis of new acridines and hydrazones derived from cyclic $\beta$-diketone from cytotoxic and antiviral evaluation. Eur J Med Chem. 44 (2009) 3680-3686.

[16] R. Kalsi, K. Pande, T. N. Bhalla, J. P. Bartwall G. P. Gupta, S.S. Parmar, Anti-inflammatory activity of quinazolinoformazans. J Pharm Sci. 79 (1990) 317-320.

[17] W.H. Lewis, Ribonucleotide reductase from wild type and hydroxyurea-resistant chinese hamster ovary cells. Cell Physiol. 87 (1978) 97.

[18] P. Reichard, From RNA to DNA, why so many ribonucleotide reductases. Science, 260 (1993) 1773-1777.

[19] J. A. Wright, A. K. Chan, B. K. Choy, R. A. Hurta, G. A.McClarty, A. Y. Tagger, Regulation and drug resistance mechanisms of mammalian ribonucleotide reductase, and the significance to DNA synthesis. Biochem Cell Biol. 68 (1990) 1364-71.

[20] H. Eklund, U. Uhlin, M. Farnegardh, D. T Logan. P. Nordlund, Structure and function of the radical enzyme ribonucleotide reductase. Prog Biophys Mol Biol. 77 (2001) 177-268.

[21] J. M. Cocking, Gene for M1 subunit of ribonucleotide reductase is amplified in hydroxyurearesistant hamster cells. Somat cell mol Genet. 13 (1987) 221. 